\author{
BARBARA OSÓCH \\ University of Szczecin, Poland \\ KARINA TESSAR \\ University of Szczecin, Poland
}

\title{
Diversification of Social Capital of Sailing Community and Development of Tourist Services of the Szczecin Lagoon
}

\begin{abstract}
The aim of the present paper is to show the impact of the diversity of social capital of the international sailing environment on the development of tourist services around the Szczecin Lagoon and Dąbie Lake. The target group are Polish and German participants in nautical tourism in the cross-border research area. Materials for the article were collected during field studies conducted in 2009-2012. The questionnaire method was mainly used to obtain information. The paper uses elements of social capital for the purpose of creating the image of the place and promotional activities of the region. The sources of capital were: motivations for sailing, additional leisure time activities, form of sailing activity, individual choice of a place of rest as well as the most frequently chosen domestic and international destinations, as well as personal data like gender, age and nationality of respondents. Understanding capital as a resource allowed it to be used for the development of the research area. The analysis of the research results allowed to specify one characteristic which was positively evaluated by two groups of respondents and these are landscape conditions of the Szczecin Lagoon. Contact with nature turned out to be the most important motivation for sailing. On the other hand, the heterogeneity of the Polish and German sailing environment is clear in the context of age, sailing qualifications, property status, which determines the direction of cruises undertaken and other activities accompanying sailing. All the above-mentioned elements of social capital bring benefits for the research area, observed in the economic and social dimension. Based on them, promotional and infrastructural changes were proposed for the needs of the tourist services sector, including, among others, nature, cultural or qualified tourism.
\end{abstract}

Keywords: Dąbie Lake; sailing; social capital; Szczecin Lagoon, tourist services

Received: 27 December 2018

Accepted: 23 May 2019

\section{Suggested citation:}

Osóch, B., Tessar, K. (2019). Diversification of Social Capital of Sailing Community and Development of Tourist Services of the Szczecin Lagoon. Prace Komisji Geografii Przemysłu Polskiego Towarzystwa Geograficznego [Studies of the Industrial Geography Commission of the Polish Geographical Society], 33(3), 85-99. doi: $10.24917 / 20801653.333 .6$

\section{INTRODUCTION}

Szczecin Lagoon as an area is attractive because of its size (the largest water reservoir in Poland), location (on the border between Poland and Germany), varied nautical 
conditions (unique in the country scale combination of inland waters and internal sea waters), diverse natural and anthropogenic conditions and cultural diversity, multiplicity and diversity of ports and harbours (Fig. 1). These advantages suppport establishing international contacts in the entire Pomerania Euroregion and in consequence stimulate the development of diverse tourist services, in a broad sense, as all immaterial benefit resulting from conducted activity e.g. tourist. However in narrower meaning it refers to the carriage of passengers and accommodating to purposes other than long-stay.

The diversity of places, the universality of tourist services and the large diversity of tourist groups impose further narrowing of tourism activities resulting from the need to adapt the tourist offer to the expectations of specific groups of recipients (Payne, 1997; Waters 2001; Kasiewicz, 2002; Kotler, 2002; Kolman, 2003; Leja, 2003; Salmanowicz, 2003; Urbaniak, 2004; Czapliński, Rachwał, Tobolska, Uliszak, 2013).

The implementation of the above postulate, combined with a thorough analysis of the social capital of participants of nautical tourism on the discussed basin, allows for the proposal of promotional activities and infrastructural changes for the needs of the tourist services sector, including natural, cultural or qualified tourism.

The components being the subject of the article, i.e. natural and touristic values of the Szczecin Lagoon, the social capital of sailors and tourist services are an interesting topic of discussion. However, it is only in the comparative approach that they create a research problem that has not been previously addressed in the literature on the subject. The authors have therefore attempted to answer the question: can the social capital of the sailing environment have an impact on the range of tourist services provided? It should be remembered that the desire to obtain an answer to the above question determines the location of the reservoir on the border between two countries, which affects the shaping of heterogeneous attitudes and patterns of behaviour of users of this reservoir. Hence the assumption of the concept of "habitus" ${ }^{1}$ by P. Bourdieu that the same places can differentiate personal experiences, expressed opinions and the ability to perceive respondents created in different material or cultural conditions (Miossec, 1977).

The border on the Szczecin Lagoon divides the reservoir into the German Small Lagoon in the West, which according to the water law (Act of 18 July 2001 Water Law) belongs to inland waters (Dąbie Lake is also on the list of inland waterways) and the Polish Great Lagoon in the East, included in the internal sea waters. The Międzyodrze area and the Szczecin Lagoon are a part of the water route linking the inland routes of Western Europe with the Baltic Sea. It leads from Berlin through the Odra-Havel channel through Szczecin (or Dąbie Lake), the Szczecin Lagoon and further to the Pomeranian Bay on the Baltic Sea. Dąbie Lake is therefore the only lake in Poland which is available to seagoing vessels. Poland's entry into the Schengen zone has removed all obstacles in the movement of sailors in the border zone between the ports and marinas of neighbours. The fairway marked out in this way shows differences in the water landscape of Poland and Germany. On the German side of the Lagoon we will see only the ships of the white fleet, sailing yachts and motor yachts. The Polish part is available for, among others, seagoing cargo ships, barges, passenger ships, ferries, tugs (Furmaga, Wójcicki 1993).

\footnotetext{
${ }^{1}$ Habitus (latin), efficiency - the system of thought patterns, perception, evaluation and action; a concept proposed by Pierre Bourdieu
} 
Figure 1. Area of research - Szczecin Lagoon and Dąbie Lake

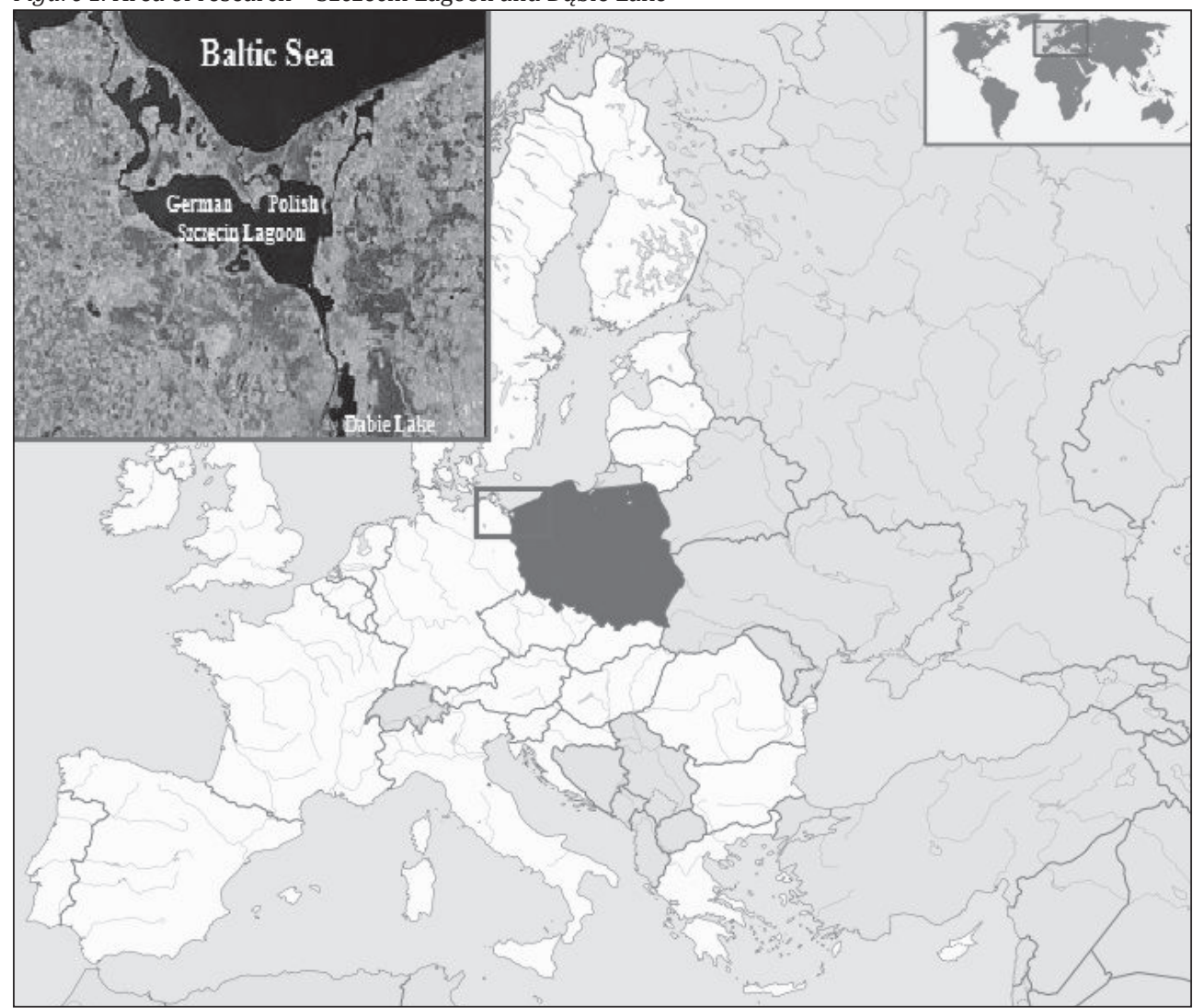

Source: authors' own work based on www.zalew.org

\section{METHODS AND THE SCOPE OF RESEARCH}

The aim of empirical research was to show the impact of the diversity of social capital of the international sailing environment on the scope of provided tourist services. The selection of the research area was a purposive sampling. Three specific problems were created for the purpose of this study:

1. Is there any diversity in the sailing environment of the Szczecin Lagoon?

2. Can sailing be an element of the region's image?

3. Are the provided tourism services adapted to the expectations and needs of sailors?

The survey was conducted in 10 Polish and German marinas around the Szczecin Lagoon and Dąbie Lake. They were selected on the basis of location, size and availability. Three consecutive sailing seasons 2010-2012 were provided with the questionnaire survey, in addition the accumulation of secondary data was commenced already in 2009. The equal number of marinas was surveyed on the Polish and German sides. The tests were carried out simultaneously in all marinas and additionally during major sailing events and celebrations. The location of marinas and their size indicative of the number of boats to be accommodated, as well as the number of resident and visiting 
sailors were the decisive factors for inclusion in the survey. In this report, the empirical study covered a group of 712 sailors - 463 Polish and 249 German ones.

The basis of the collected information was standardized research - direct interviews and written interviews with participants of nautical tourism (Babiński, 1980; Denzin, 2006, 2009; Smith, 2010), which were supplemented, mainly in terms of lifestyle and ways of spending free time, using the observation method (Sztumski, 2005). The questionnaire (Trochim, 2002; Punch, 2005) consisted of 39 questions, ten of which were related to respondents' particulars. The questions were open or closed, single and multiple-choice, including matrix questions with a specific number of answer columns and matrix semantic ones whose answers illustrating the states of feelings, emotions and assessments of respondents could be rated along the scale.

Only part of the questions was used to analyse the questionnaire. It was assumed that the social capital of the cross-border sailing environment is characterised by the motivation of sailing, additional leisure activities, forms of sailing activity, individual choice of a place of rest, as well as the most frequently chosen domestic and foreign destination. The report made it possible to identify respondents by nationality, gender, age, water rights and annual expenses for yacht or sailing activity.

The research limitations include the lack of answers in some questionnaires, which resulted in varying the final number in individual categories. The control group was examined, which provided a complete set of data in the cross-section of the responses. Comparison of the control results with the target ones did not show significant deviations, and therefore the number of the given category was assumed for $100 \%$ each time. The analysis of collected statistical data was carried out using the segmentation method (Florek, 2013). The application of the nationality criterion made it possible to divide the sailing environment into homogeneous groups of consumers. Classification of sailing motivations was carried out using the taxonomic method - cluster analysis (agglomeration). It was created on the basis of the smallest variance method - the Ward method (grouping of motivations) (Stanisz, 2007; Panek, 2008). Five clusters were obtained, the names of which were proposed on the basis of observation of the behaviour of individuals. In their selection, the analogy of personality attitudes of mountain climbers was also helpful, which, unlike sailing issues, is richly discussed in literature (Ziemilski, 1976; Zdebski, 1984).

\section{SOCIAL CAPITAL UNITS IN SAILING}

For the purposes of this study, we adopted those definitions of social capital which focus on the value of interpersonal cooperation undertaken within organisations or groups to achieve their own goals (Coleman, 1990; Putnam, 1993, 1995, 2008; Fukuyama, 1995, 1997, 2003; Harrison, Huntington, 2003; Sztompka, 2005; Trutkowski, Mandes, 2005). According to R. Putnam, economic growth is mainly facilitated by the interpersonal relations that are established in larger social structures. For this reason, this study focused on the division of local sailing community according to nationality rather than, for instance, membership of individual clubs. This allows for the creation of effects for the whole cross-border region. The social capital of the sailing community in the Szczecin Lagoon and Dąbie Lake was examined on the basis of the following data:

- annual expenses on yacht maintenance (as an attempt to show discrepancies in expenses); 
- the type of sailing, meeting friends, making new friends and participating in events (demonstrating interpersonal relationships and social-family networking);

- sailing licence types, motivations for sailing, activities accompanying organised cruises (interpreted as habits and standards of behaviour);

- club membership or organisation of cruises on a club-owned boat (evidence of voluntary membership of organisations);

- main destinations of cruises during the surveyed sailing season: domestic vs. foreign destinations and the choice of accommodation (to show personal preferences of respondents).

The precise identification of sailing cruise destinations is determined by cruises heading for: the Polish/German part of the Szczecin Lagoon, other regions of Poland and Germany, or other countries. The choice of accommodation places was limited to four categories to be specified by respondents: boat, hotel, camping or tent. However, motivations to undertake sailing activity called for an appropriate classification. They were grouped into five categories, distinguished on the basis of individual components of social capital (table 1$)$ :

Table 1. Motivation as a component of social capital

\begin{tabular}{|l|l|l|}
\hline \multicolumn{1}{|c|}{ Motivation for sailing } & \multicolumn{1}{|c|}{ Personal traits of respondents } & \multicolumn{1}{|c|}{ Components of social capital } \\
\hline Contact with people & $\begin{array}{l}\text { Sociable, open to entering into } \\
\text { new and sustaining the existing } \\
\text { relationships }\end{array}$ & $\begin{array}{l}\text { Participation in events, meeting } \\
\text { friends, making new friends, } \\
\text { spending time with family }\end{array}$ \\
\hline Need for isolation & $\begin{array}{l}\text { People isolating themselves not } \\
\text { only from other people, but also } \\
\text { from the excess of stimuli }\end{array}$ & $\begin{array}{l}\text { Spending time away from the } \\
\text { family, relax, peace, independence }\end{array}$ \\
\hline Dominance and competition & $\begin{array}{l}\text { People happy in the leader's } \\
\text { role, building their self-esteem } \\
\text { around achievements, primarily } \\
\text { through competing, and enjoying } \\
\text { adrenaline rushes }\end{array}$ & $\begin{array}{l}\text { New experiences, rivalry, } \\
\text { independence, leadership, } \\
\text { fighting the forces of nature, } \\
\text { strong experiences, impressing } \\
\text { others and taking risks }\end{array}$ \\
\hline Contact with nature & $\begin{array}{l}\text { Lovers of nature and outdoor } \\
\text { activities }\end{array}$ & $\begin{array}{l}\text { Communing with nature, } \\
\text { spending time away from the } \\
\text { city, getting to know new areas, } \\
\text { spending time on the water, relax, } \\
\text { peace and spiritual values }\end{array}$ \\
\hline Education and self-improvement & $\begin{array}{l}\text { People open to lifelong learning, } \\
\text { broadening their knowledge and } \\
\text { improving their own skills and } \\
\text { the skills of the entire sailing } \\
\text { community }\end{array}$ & $\begin{array}{l}\text { Sharing the knowledge, discussing } \\
\text { the equipment or gaining new } \\
\text { experiences. }\end{array}$ \\
\hline
\end{tabular}

Source: authors' own work

In addition, social capital of the sailing community was reviewed in terms of four aspects: individual, structural, regulatory and behavioural (Markowska-Przybyła, 2011). The individual aspect of social capital is a collection of personal traits and preferences of respondents, such as: nationality, gender, age, expenses on a yacht, activities accompanying sailing (e.g. diving, fishing, sunbathing, etc.) and the choice of accommodation standard or cruise destination. The structural aspect demonstrates a network of connections between members of the group surveyed, e.g. how the cruises are organised (privately-owned boat, club-owned or chartered one) or the dominant manner of 
sailing (e.g. sailing alone, with family, as a club member or a course participant, etc.). The regulatory aspect refers to social norms, interpreted here as e.g. holding sailing licences or observing a tradition of competing in regattas. The behavioural capital is based on specific manifestations of cooperation, which include i.a. the exchange and flow of information as well as educational and cognitive values.

\section{SOCIAL CAPITAL OF THE SAILING COMMUNITY}

Polish sailors constituted the majority (65\%) of respondents. On average, a Polish sailor is a man aged 35 who holds a sailor's licence. He sails his own boat, using it for family holidays and for tourism. He mainly sails in the Polish part of the Szczecin Lagoon, and if he cruises abroad, he chooses a destination other than neighbouring Germany. He stays overnight mainly on the boat. He combines sailing primarily with sightseeing and sunbathing, less frequently with trekking or fishing. In addition to a keen contact with nature, he also demonstrates a desire for leadership and interest in competing. Less frequent motives to practice sailing for him are - in equal measures - willingness to contact others as well as isolation. The cognitive and educational values occupy the last place on his list of motivations. Yacht maintenance costs him on average between 250 and 1,250 EUR per season.

An average German sailor, on the other hand, is a man over the age of 55. He usually does not hold any sailing licence. He owns his sailing boat, but it is worth noting that he does not organise any cruises on boats owned by his friends or by sailing clubs or on chartered boats. He sails primarily domestically, but not in the Szczecin Lagoon, and if he sails abroad he chooses destinations in the Polish part of the Szczecin Lagoon. He sleeps on his own boat. He sails mainly with his family, combining this activity with cycling tours - another passion, for which he is known. He highly appreciates contact with nature. His motivation for sailing is again competition and leadership, along with a desire for seclusion. On average, he spends between 1,000 and 5,000 EUR on his yacht per season.

The basis for the comparative analysis of tourist behaviour of Poles and Germans is the assumption about the impact of cross-border issues and the resulting differences in spatial conditions on the formation of different types of sailors. The diversity of the sailing community results from differences in the cultural environment, the education system, legal regulations in force in a given country, or social and material status achieved, with which German and Polish sailors begin and continue practicing this sport, are a significant and obvious reason for their differentiation. On the basis of the analysed characteristics, however, both similarities and differences between the two groups are clearly visible (Figure 2).

In order to address the regional offer to both Polish and German sailors, it should be tailored for men who belong to two different age groups: in the case of Poles - 35 year old, while Germans - over 55 years of age. This is probably related to the ageing of German society (Population Pyramid Germany, 2017). This is an extremely important criterion, as the needs of young people, who are either at the start of their career or have already reached the stage of prosperity and family life, differ significantly from the needs of people who are close to or have reached the end of their career path, have a different social status and, above all, a different amount of free time, usually associated with greater financial stabilisation or having no dependent children. The financial 


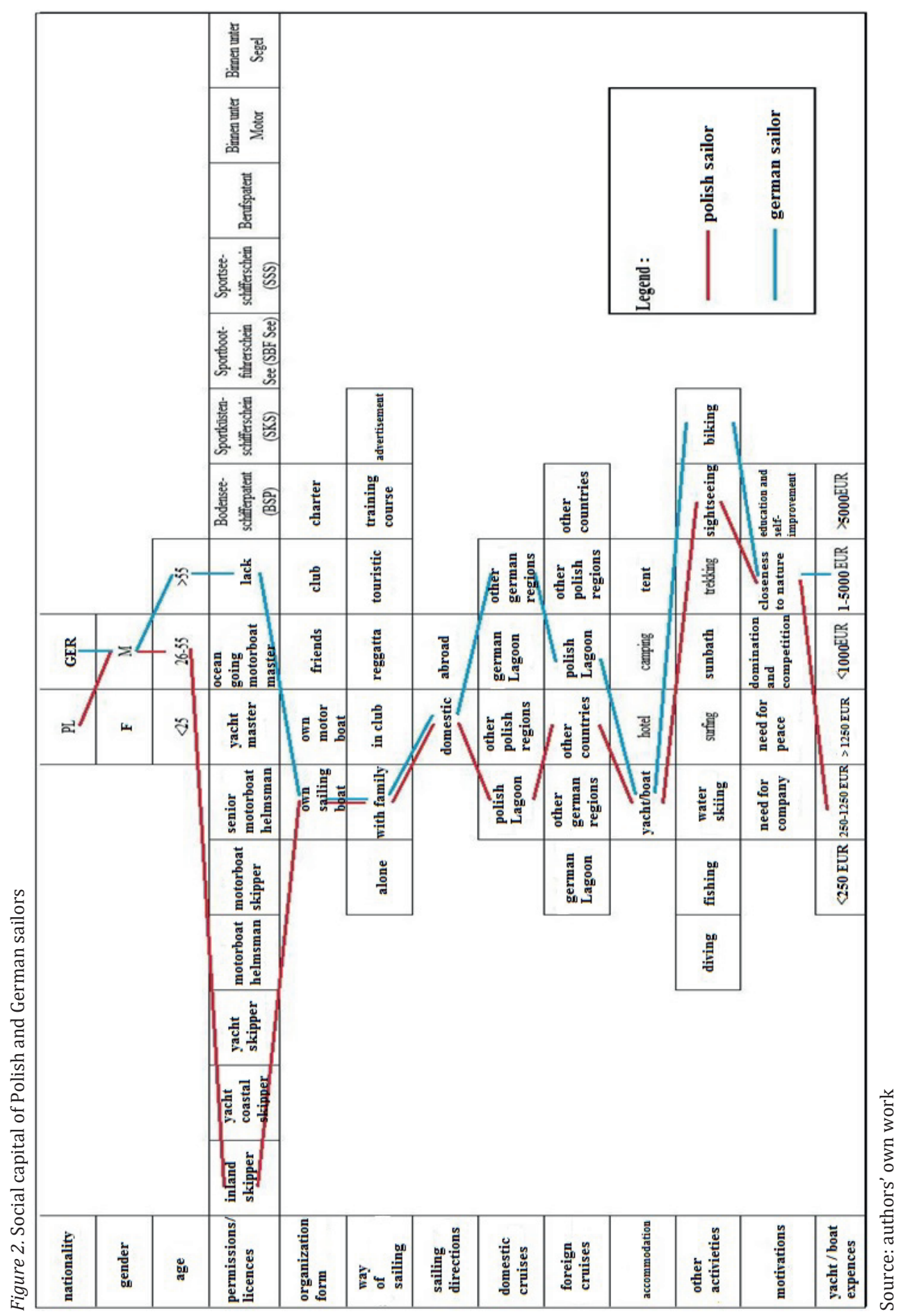


aspect is not allowed for in this paper, because, when looking at the national criterion, a comparison of the lifestyle of Polish and German pensioners clearly indicates greater economic leeway of the latter, manifesting itself, inter alia, in their activity and participation in tourism (Kowalczyk, 2013; Dlaczego Polacy... [Why Don't Poles...], 2016). This is also confirmed by their expenses for yacht maintenance. In real terms, the expenditure of German sailors are higher (1,000-5,000 EUR) compared to Polish sailors (250-1,250 EUR). Differences in the financial status also seem to translate into the preferred form of cruise organisation. While all the surveyed German sailors own their vessels (sailing boats or motorboats), in the Polish group they account for less than three quarters of the respondents (71\%). This most likely also translates into the fact that Poles enlist on a yacht in response to an advertisement, which is a relatively lowbudget form of participation in a cruise, while the Germans do not practice such a cruise arrangement method.

While recognizing certification/licensing as a component of sailors' social capital, it should be mentioned that sailing is legally regulated on both sides of the Szczecin Lagoon, which is an effect of the classification of the basin according to the law on use and conservation of inland waters. The knowledge of and adherence to separate regulations resulting from this diversification constitute an important component of the social capital of the group surveyed. However, most (53\%) of the surveyed German sailing community do not hold any sailing licence as there is no such requirement in Germany. On the other hand, the Poles hold mainly (27\%) certificates of basic skills only.

Considering the dominant cruise destinations, it may be stated that both Poles (85\%) and Germans (92\%) sail primarily within their domestic waters. Seventy-five percent of Poles choose the Szczecin Lagoon, and the others opt for other regions of Poland, mainly Kołobrzeg or the Tri-City of Gdańsk, Gdynia and Sopot. This may result from the location of our survey. Exactly the opposite proportions were observed in the domestic cruises of German sailors. A vast majority of them sail in regions other than the Szczecin Lagoon. Keeping in mind the poorer landscape values of the German part of the Lagoon, German sailors usually head for the Rügen region, where nautical conditions also present greater diversity. Foreign destinations are more often selected by Germans (83\%) than Poles (65\%). German sailors appreciate mainly the Polish part of the Lagoon (48\%) due to its natural values, low cost of stay and cruise arrangement. Poles head for countries other than Germany (57\%) - mainly for Scandinavian countries: Denmark (including Bornholm) and Sweden.

The Baltic Sea Region - Zachodniopomorskie Voivodeship and Mecklenburg-West Pomerania - with a highly branched network of Hanseatic cities, in the Middle Ages was the leading economic region of Europe. Today, the greatest asset or benefit, distinguishing it from other regions of the country, are the values of the natural environment, as evidenced by, for example, the research done in 1994, 1997 and 1999 by the Tourismus Verband institution on the associations of tourists with the Mecklenburg Region of Western Pomerania (Schernewski, Sterr, 2002; Haller, Stybel, 2011; Jacobsen, 2018). The Zachodniopomorskie is the leading region of Poland (just behind Małopolska) in the number of overnight stays - 5.5 million in 2018 (GUS, 2018). In 2017, Meklenburg recorded more than 29.5 million overnight stays (Government-mv), which makes it a region of long-stay and family tourism. The natural attractiveness consists of the location in the coastal zone, high coverage of water areas $5.2 \%$ of the Zachodniopomorskie Voivodeship, which is almost 2.5 times more than the average for Poland (GUS 
2013: 121) and 5\% of the area of Mecklenburg-Western Pomerania, which is $25 \%$ of the German lake area), a dense river network, high forest cover $-36.4 \%$ of the province's area, where the average in the country is 29.9\% (GUS 2013). The natural values of Zachodniopomorskie and Mecklenburg are protected (Dudley, 2008) through national parks (2 and 3), biosphere reserves (3 in Mecklenburg), protected landscape areas (7 in Mecklenburg), landscape parks ( 7 and 149), nature reserves (7 and 286 in Mecklenburg), the Natura 2000 network (21 bird sanctuaries and 295 in Mecklenburg), natural monuments (2842) (lung.mv-regierung.de, gdos.gov.pl). These elements create perfect conditions for active recreation: water sports, cycling, hiking and horse riding.

The sailors' choice of accommodation is conditioned by their lifestyle. The majority of Germans (96\%) and Poles (85\%) stay on their boat at night. This way of sleeping creates a specific atmosphere, providing all the comfort during the cruise and does not generate additional cruise costs, because the mooring fee of the marina includes an overnight stay. Only few sailors opt for other accommodation facilities - 3-5\% of the surveyed Poles and a marginal $0.5-1 \%$ of the Germans. This situation is probably explained by low-class yachts or open motorboats used, which are not equipped to provide accommodation on board.

Interesting results are also produced by the analysis of other activities undertaken by the respondents during sailing. In both cases, sports such as surfing (Poles 4.5\%, Germans 1\%) or water skiing (Poles 2.5\%, Germans 1.5\%) are so marginal that they can be considered insignificant in terms of planning. There are many reasons why these activities are extremely rare, ranging from the lack of conditions (including natural factors and technical infrastructure), through fashion for other activities, to popularity of these sports in other age groups. Instead, planners should pay much attention to sightseeing, which is an inseparable component of sailing for a significant group of Polish (29\%) and German (23\%) sailors. However, there is a huge difference in the popularity of cycling tours. Germans are three times more likely to undertake cycling tours (25\%) than Poles (8\%). Both groups show similar levels of hiking, trekking, sunbathing and fishing activities, which is naturally related to sailing.

In terms of social capital's components, it also seems extremely important to analyse the drivers of sailing activity. Slightly more Poles (46.5\%) than Germans $(37.5 \%)$ are primarily interested in contact with nature. The disproportion may again results from a different characteristic of the distinguished groups of sailors and their way of spending free time. For young Poles, the highest value and the most valuable springboard from an intensive lifestyle will be contact with nature. Retired Germans, who practice recreation in green areas on a daily basis, do not show such spontaneity in its assessment. The motives related to rivalry and leadership are twice more likely to entice Poles (33\%) than Germans (17.5\%) to sailing. This is due to the lower age of Polish sailors. The same factor also causes greater willingness to contact people (Poles $21 \%$, Germans 16\%). The need for isolation and spending time in solitude is shown by a similar number of respondents (Poles 21\%, Germans 17.5\%). Poles appreciate the educational and cognitive aspects of sailing slightly more than Germans. Again, this can be related to the age of the respondents and results not only from young people's interest in modern solutions, technologies and gadgets, but also from the family-oriented way of sailing and thus passing the knowledge from one generation to another, as this age group often includes families with infants or teenage children. 


\section{DISCUSSION AND RECOMMENDATIONS}

Due to the cross-border location of the area in question, respective Polish and German nationalities were adopted as the main criterion for dividing the respondents. The complementary criterion was diverse sources of capital, the aggregation of which allows to maintain the local context (e.g. different legislations in force within a single water body), without which the picture of the social capital of a given community, based solely on individual data, would be misleading (Markowska-Przybyła, 2011). In accordance with the principle of mutual attractiveness (Florek, 2013), not only social capital is important as a regional value, but also the Lagoon's attractiveness for its users. A seemingly homogeneous water body with similar parameters, with mutually balancing components of the natural and cultural environment, was valued differently by Polish and German sailors (Osóch, 2015). Poles and Germans unanimously appreciated nature surrounding the Lagoon, as well as the changing landscape conditions on the sides of the Small and the Large Lagoon. This is the only feature of the area in question that was positively evaluated by both national groups. In addition, Poles appreciated the attractiveness of the surrounding land, a wide range of tourist attractions on land, the adequate infrastructure of marinas and wharves, as well as the multitude and diversity of marinas on the German side. On the other hand, the Germans recognised the advantages of water bodies that consist in proper navigation markings and a well-developed safety system for sailors; they appreciated the clean water and low costs of mooring and catering services in Polish marinas (Osóch, 2015).

The most important components of social capital of the sailing community of the Szczecin Lagoon and Dąbie Lake will allow proper targeting of the region's offer to males of both nationalities over the age of 26 who sail and spend the night with their families on their own sailing boats, spending between 250-5,000 EUR respectively on the boat's maintenance, who appreciate direct contact with nature, cycling tours and sightseeing opportunities within the visited areas.

One of the most important benefits arising from the presence of sailors a group with a significant social capital - in the Szczecin Lagoon is the possibility of creating a cohesive and attractive image of the region. They are a group of tourists visiting the region of the Lagoon and also consumers of tourist services. Due to the cross-border nature of the area, promotional activities, taking into account the needs and expectations of sailors, should go to a wider group of recipients and can facilitate the acquisition of foreign investors for planned projects. These activities, in terms of investment, may include solutions aimed at adapting the infrastructure of the area to the characteristics of the sailing community described herein, e.g creating a common system of bicycle paths and routes (the cycling route around Szczecin Lagoon in the German part leads mainly bicycle paths and in the Polish part mainly public roads) as well as biking equipment rentals, and also - due to the dominant family travel model - establishment of parks and squares for family entertainment (such as the zoo in Ueckermünde, a playground and the Karls farm in Koserow, a rope park in Świnoujście).

The cross-border aspect of the area also creates the need for mutual understanding and cooperation between the Polish and German sides in order to achieve mutual benefits. Since almost 50\% of the German respondents are eager to visit the Polish side of the Lagoon during international cruises, and since there is also a group of Poles who sail 
to the German side (16\%), foreign language service is necessary for the development of international contacts in places such as tourist information desks, marinas, as well as lodgings and restaurants. It is also worth noting that the availability of information materials in various language versions (e.g. press, leaflets, folders or websites), at least in the tourist sphere and especially on the Polish side, seems insufficient. The standard of activity of tourist information centres should include regular mutual exchange of promotional materials, as well as presentation of the entire region's offer.

Knowledge of the sailing community could result in the creation of tourist products in the form of single-day excursions, as the nature of cruises undertaken by respondents does not encourage long-term stays in one place. They should refer to the characteristics of the area, which is the greatest value for sailors, that is the natural character and diversity of the landscape: on the German side, somewhat monotonous, but rich in lowland areas, while on the Polish side it is for high and low coasts, natural and artificial islands. Both sides of the Szczecin Lagoon are characterised by a similar length of the shoreline (about $250 \mathrm{~km}$, including $50 \mathrm{~km}$ of sea line) and about $20 \%$ of the area of the voivodeship and the state with diverse forms of nature protection. The spectrum of possibilities of rest in the natural surroundings is therefore wide.

Despite the fact that both countries belong to the Schengen Area and despite the resulting freedom of movement, the way in which the interpersonal relations are affected by the border still calls for investigation: does the border connect people or rather separate them? Based on the case study of the cross-border area of the Szczecin Lagoon, we can state that there are noticeable benefits in the form of easy movement of sailors across the previously artificially divided water body. The common history of this area may be an important factor that can contribute to the use of social capital of the sailing community in building and achieving positive external effects. It can be used to build mutual product awareness on both sides of the border, using bottom-up initiatives or various institutional projects. An example of such activities are the efforts to preserve the culinary traditions of the region. The roll with herring has been a typical snack for decades, which at present can be found in many bars (restaurants on land and water, bistro and beach bars or trendy in recent years of mobile gastronomy called food truck) on the German side of the Lagoon, but it has not been restored as traditional food in Szczecin despite several years of attempts.

The common historical background can also be observed in the white Stettiner Ware ceramics in Szczecin, which was revived in 2013 as part of the "Stettiner Ware - a local product" project and which can now be seen at the Museum of Technology and Transport in Szczecin. However, the combination of ceramics with technology and communication is not obvious, so it is not surprising that the brand awareness is not widespread yet.

On the other hand, on the German side of the Szczecin Lagoon, in the public space of the village of Ueckermünde, one can find a decorative mural that informs about its history, thus reaching a wide audience with a simple message.

There was also introduced a system of nautical motifs in the small architecture of the city, e.g. in the form of street lanterns, in the shape reminiscent of masts with a sail, which constitute the background of advertisements and posters. The Polish side is also rich in maritime elements incorporated into the network of streets, mainly anchors and monuments of merited sea people, but they do not form a cohesive whole, which could constitute even a nautical tourist route. The predominance of Szczecin in the Lagoon 
region is also emphasiszed in the naming of many service premises in Germany (e.g. Stettiner Hof), but the city name is rarely used in this way on the Polish side.

\section{CONCLUSIONS}

The idea of tourism services by definition is "all socially useful activities that are aimed at satisfying the material and immaterial tourist needs of people" (Gaworecki, 2003). The tourist market offers a wide range of tourist services, tailored to their needs and requirements. They appear as individual services or a package. A characteristic feature is their complementarity, signifying mutual dependence, satisfying tourist demand, including sailors.

The conducted research leads to conclusions resulting from the main and detailed questions posed at the beginning.

The clear differentiation of the sailing environment has a significant impact on the scope of tourist services provided. Diversifying the offer and, to a greater extent, adapting it to the needs of sailors and their preferred forms of spending free time will increase the tourist attractiveness of the region, which as a consequence may become a popular destination for sailors from the whole Pomerania Euroregion. An example may be the Tall Ships Races sailing into the calendar of cyclical sailing events, combined with regattas and special events. In the discussed region, the capital of the rally is the city of Szczecin, attracting thousands of sailing enthusiasts.

There are reasons to argue that the sailing motif becomes an important element of the image of the region, cities and towns around the Szczecin Lagoon - e.g. in the form of common architectural details, culinary traditions, etc. This will allow for a coherent message that will be beneficial not only in the reception aesthetic, but also sentimental, giving the opportunity to associate a place with its natural surroundings. An example can be all year round stationary or mobile fish bars in yacht ports, satisfying the most important needs of sailors, and at the same time being a pleasant, different escape from their everyday habits.

There is heterogeneity of the sailing environment of the Szczecin Lagoon, which provided the basis for distinguishing two personal profiles of sailors. The division was made based on elements of sailing capital (obtaining answers, among others, about age, sailing method, additional forms of activity during cruises and sailing motivations, which induce tourist activities). This diversification will in the future facilitate the selection of an appropriate tourist offer, which can be provided for sailors visiting the area of the Szczecin Lagoon, however, services in the field of tourism do not require the creation of an offer only for tourists-sailors. They can be used by all willing recipients. However, the specificity and nature of leisure activities by sailors gives the opportunity to adapt certain tourism services to their needs and preferences, as, for example, a network of bicycle paths facilitating access to natural and non-natural values, in which the seaside region abounds.

The above observations may be applied and used in planning by institutions, unions and associations based on a similar area. Those include, for instance: "Cross-Border Cluster - Berlin-Szczecin-Baltic Waterway", the Union of Ports and Marinas or the Local Tourist Organisation of the West Pomeranian Sailing Route. Every year, the growing tourist offer on both sides of the border is the effect of promotional activities aimed at unifying the scope of tourist services provided to international visitors. Suggested 
directions for development are reflected in adjusting the offer for tourists. School education at every stage of education, as well as cooperation with the management of protected areas in the discussed area allow you to get good advice and learn about the positive use of the richness of nature.

\section{References}

Babiński, G. (1980). Wybrane zagadnienia z metodologii socjologicznych badań empirycznych. Kraków: Uniwersytet Jagielloński.

Centralny Rejestr Form Ochrony Przyrody (2019, 20 May). Retrieved from http://crfop.gdos.gov. $\mathrm{pl} / \mathrm{CRFOP} / \mathrm{search} . \mathrm{jsf}$

Coleman, J. (1990). Foundations of Social Theory. Cambridge, MA: Harvard University Press.

Czapliński, P., Rachwał, T., Tobolska, A., Uliszak, R. (2013). Geografia gospodarcza. Przewodnik do ćwiczeń. Poznań-Kraków: Bogucki Wydawnictwo Naukowe.

Denzin, N. (2006). Sociological Methods: a Sourcebook. Aldine Transaction.

Denzin, N.K., Lincoln Y.S. (2009). Wprowadzenia. Dziedzina i praktyka badań jakościowych. In: K. Podemski (ed.). Metody badań jakościowych. Tom 1. Warszawa: Wydawnictwo Naukowe PWN.

Dlaczego Polacy nie podróżują? [Why Don't Poles Travel?] (2016). Retrieved from http://eksploratorka.pl/dlaczego-polacy-nie-podrozuja/

Dudley, N. (2008). Guidelines for Applying Protected Area Management Categories. Gland, Switzerland: IUCN.

Dudley, N., Stolton, S. (2008). Defining protected areas. An International Conference in Almeria, Spain. Gland, Switzerland: IUCN.

Florek, M. (2013). Podstawy marketingu terytorialnego [Basics of Territorial Marketing]. Poznań: Uniwersytet Ekonomiczny w Poznaniu.

Fukuyama, F. (1995). Zaufanie: kapitał społeczny a droga do dobrobytu [Trust: The Social Virtues and The Creation of Prosperity]. Warszawa/Wrocław: PWN.

Fukuyama, F. (2003). Kapitał społeczny [Social Capital]. In: L.E. Harrison, S.P. Huntington (eds.). Kultura ma znaczenie [Culture Matters: How Values Shape Human Progress]. Kraków: Zysk i S-ka.

Furmaga, L., Wójcicki, J. (1993). Mały słownik morski. Gdynia: Mittel International.

Gaworecki, W. (2003). Turystyka. Warszawa: PWE.

Gudmundsson, G. (2012). Koncepcja kapitału społecznego i jej zastosowanie w badaniach edukacyjnych. Studia Edukacyjne, 22, 55-79. Retrieved from https://repozytorium.amu.edu.pl/ bitstream/10593/5897/1/55-80.pdf

GUS (2013). Ochrona środowiska 2013. Warszawa.

Haller, I., Stybel, N., Schumacher, S., Mossbauer, M. (2011). Will Beaches be enough? Future Changes for Coastal Tourism at the German Baltic Sea. Journal of Coastal Research: Special Issue 61 - Management of Recreational Resources, 70-80. Retrieved from https://www. jcronline.org/doi/full/10.2112/SI61-001.68

Harrison, L.E., Huntington, S.P. (eds.) (2003). Kultura ma znaczenie. Jak wartości wpływają na rozwój społeczeństw [Culture Matters: How Values Shape Human Progress]. Poznań: Zysk i S-ka.

Jacobsen, B. (2018). State of the Tourism Industry in the Baltic Sea Region 2018 Edition. Retrieved from https://bstc.eu/fileadmin/bstc.eu/Downloads/Final_Report_Tourism_Industry_in_ BSR_2018.pdf

Kasiewicz, S. (2002). Zarządzanie operacyjne w dobie globalizacji. Warszawa: Wydawnictwo Difin.

Kolman, R. (2003). Zastosowania inżynierii jakości. Poradnik. Bydgoszcz: AJG Oficyna Wydawnicza.

Kotler, Ph., Armstrong, G., Saunders, J., Wong, V. (2002). Marketing. Podręcznik europejski. Warszawa: PWE.

Kowalczyk, M. (2013). Retrieved from http://www.rp.pl/artykul/1020966-Niemcy-podrozuja-czesciej-i-chetniej.html\#ap-1

Landesamt für Umwelt, Naturschutz und Geologie (2019, 20 May). Retrieved from https://www. lung.mv-regierung.de/insite/cms/umwelt/natur/schutzgebiete_portal/schutzgebiete_listen.htm 
Leja, K. (2003). Instytucja akademicka. Strategia, efektywność, jakość. Gdańsk: Gdańskie Towarzystwo Naukowe.

Markowska-Przybyła, U. (2011). Kapitał społeczny - wybrane problemy pomiaru [Social Capital - Selected Problems of Measurement]. In: Przekształcenia regionalnych struktur funkcjonalno-przestrzennych. Współczesne kierunki przemian społeczno-ekonomicznych. [Transformations of regional functional and spatial structures. Modern directions of social and economic transformations.] Vol. 1. Rozprawy Naukowe Instytutu Geografii i Rozwoju Regionalnego Uniwersytetu Wrocławskiego, 19. Wrocław: Uniwersytet Wrocławski.

Miossec, J-M. (1977). Un modele de l'espace touristique. L'espace geographique, 1, 41-48.

Osóch, B. (2015). Sailing infrastructure and components of natural environment in the transborder area of the Szczecin Lagoon in sailors opinion. Szczecin: Volumina.pl.

Panek, T. (2008). Statystyczne metody wielowymiarowej analizy porównawczej. Warszawa: Oficyna Wydawnicza Szkoła Główna Handlowa w Warszawie.

Payne, A. (1997). Marketing usług. Warszawa: PWE.

Population Pyramid Germany 2017. Retrieved from https://www.populationpyramid.net/germany/2017/

Putnam, R.D. (1993, 1995). Making Democracy Work: Civic Traditions In Modern Italy. Princeton, New Jersey, USA: Princeton University Press.

Putnam, R.D. (2008). Samotna gra w kręgle. Upadek i odrodzenie wspólnot lokalnych w Stanach Zjednoczonych [Bowling Alone: The Collapse and Revival of American Community]. Warszawa: Wyd. Akademickie i Profesjonalne.

Sail Training International (2019, 20 May). Retrieved from https://sailtraininginternational.org/ event/tall-ships-races-2019/

Salmanowicz, B. (2003). Jakość usług e-biznesu. In: M. Fertsch, S. Trzcieliński (ed.). Praktyka zarzadzania nowoczesnym przedsiębiorstwem. Poznań: Politechnika Poznańska.

Schernewski, G., Sterr, H. (2002). Tourism and Environmental Quality of the German Baltic Coast: Conflict or Chance? file://C:/Users/root/Desktop/Schernewski.pdf

Sierocińska, K. (2011). Kapitał społeczny. Definiowanie, pomiar i typy [Social Capital - Definition, measurement and types]. In: Studia ekonomiczne, 1 (LXVIII), Polska Akademia Nauk, Instytut Nauk Ekonomicznych, 69-86.

Smith, S. (2010). Practical Tourism Research. CABI.

Stanisz, A. (2007). Przystępny kurs statystyki z zastosowaniem STATISTICA.PL na przykładach z medycyny. Statsoft, 3, Analizy wielowymiarowe. Kraków: StatSoft Polska.

Statistisches Bundesamt (2019, 20 May). Retrieved from www-genesis.destatis.de/genesis/online/link/tabelleErgebnis/45412-0021\&zeitscheiben=5

Szromnik, A. (2002). Marketing terytorialny - koncepcja ogólna i doświadczenia praktyczne [Territorial Marketing - General Concept and Practical Experience]. In: T. Markowski (ed.) Marketing terytorialny [Territorial Marketing]. Warszawa: Polska Akademia Nauk Komitet Przestrzennego Zagospodarowania Kraju.

Sztompka, P. (2005). Zaufanie, nieufność i dwa paradoksy demokracji [Trust, Distrust and Two Paradoxes of Democracy]. In: P. Sztompka, M. Kucia (eds.), Socjologia. Lektury [Readings in Sociology]. Kraków: Znak, 397-408.

Sztumski, J. (2005). Wstęp do metod i technik społecznych [Introduction to Social Methodology and Techniques]. Katowice: Wydawnictwo Naukowe „Śląsk”.

Trochim, W. (2002). Types of Surveys. Research Methods Knowledge Base.

Trutkowski, C., Mandes, S. (2005). Kapitał społeczny w małych miastach [Social Capital of Small Towns]. Warszawa: Wydawnictwo Naukowe Scholar.

Urbaniak, M. (2004). Zarządzanie jakościq. Teoria i praktyka. Warszawa: Wydawnictwo Difin.

Ustawa z dnia 18 lipca 2001 r. Prawo wodne (Dz.U. z 2005 r. nr 239, poz.2019, z późn. zm.).

Waters, D. (2001). Zarzq̨dzanie operacyjne. Towary i usługi. Warszawa: PWN.

Ziemilski, A. (1976). Człowiek w krajobrazie. Szkice z pogranicza socjologii. Warszawa: Sport i Turystyka.

Zdebski, J. (1984) (2019, 20 May). Psychologiczne i społeczne uwarunkowania taternictwa. Kraków: AWF.

Barbara Osóch, PhD, University of Szczecin, Faculty of Geosciences, Institute of Socio-Economic Geography and Spatial Management, Human Geography and Spatial Organization Unit. Long-term employee of the 
Social Geography and Spatial Organization Unit of Institute of Social and Economic Geography and Spatial Management University of Szczecin. She has graduated from Geography and received a PhD in Earth Sciences. Extensive interests in the field of social geography, sociology, water tourism and architecture have been presented in numerous publications. The main area of research interest concerns the development of geographical space for the purposes of water tourism, recreational sailing and social structure of participants in various forms of tourist activity.

ORCID: 0000-0002-8364-7904

\section{Address:}

University of Szczecin

Faculty of Geosciences

Institute of Socio-Economic Geography and Spatial Management

Human Geography and Spatial Organization Unit

ul. Mickiewicza 18

70-383 Szczecin, Poland

e-mail: barbara.osoch@usz.edu.pl

Karina Tessar, MSc, University of Szczecin, Faculty of Geosciences, Institute of Socio-Economic Geography and Spatial Management, Human Geography and Spatial Organization Unit. A graduate of Tourism and Recreation at the University of Szczecin and of post-graduate studies "Manager of scientific research and development works" at the University of Economics and Innovation in Lublin, currently an assistant in the Department of Social Geography and Space Organizations at the Faculty of Geosciences, University of Szczecin. She participated in the international project "Generation BALT", whose aim was to match the educational offer in the field of maritime economy to the changing needs of the labour market in the South Baltic Sea basin. Research interests: territorial marketing, problems of tourism development in waterfront areas.

ORCID: 0000-0001-9951-5714

\section{Address:}

University of Szczecin

Faculty of Geosciences

Institute of Socio-Economic Geography and Spatial Management

Human Geography and Spatial Organization Unit

ul. Mickiewicza 18, 70-383 Szczecin, Poland

e-mail: karina.tessar@usz.edu.pl 